coming from countries in which malaria, yellow fever and dengue are present, special prophylactic measures are necessary for destruction on the aeroplanes of the insects carrying these diseases. This prophylaxis should be carried out both on departure by a rigorous supervision of the openings in the machines and on arrival by a careful examination of the machine and a search for the hiding places of dangerous insects. The method at present employed consists in the use of a spray with various kinds of pyrethrum, though flies, ticks, bugs and other sorts of insects are not destroyed by it. Disinfestation of the machine during flight should be carried out by an apparatus containing a mixture of pyrethrum and carbon tetrachloride possessing the following characters : (I) it should be rigorously non-inflammable ; (2) it should have no injurious action on metals or materials ; and (3) it should not irritate the passengers' mucous membranes. Inspection of the aerodrome should include a search on the aeroplanes for the internal and external hiding places of mosquitoes into which ordinary disinfestants cannot enter without direct spraying. There is a general tendency to neglect entirely the outside of the aeroplanes, although it contains numerous possible places of concealment for mosquitoes.

\section{Food of Fur Animals in Captivity}

Prachically the only animals that are now being bred commercially for their fur are silver-foxes, minks and rabbits. Others have been tried, but costs of feeding, overhead charges generally, and difficulties of inducing breeding in captivity made the price of the skins greater than that of equally good wild-caught examples, so that the undertakings came to an end. To some extent, the first needs in this relatively new industry were the testing of equipment, the perfection of methods of management, and the eontrot of diseases and parasitic infestations. These problems have been tackled, but until recently no attempt had been made to discover by controlled experimental work the diets most suitable as regards results and costs for the carnivorous animals recently taken from the wild. The Yearbook of Agriculture for 1939 of the U.S. Department of Agriculture contained an article by Charles E. Kellogg on "Nutrition of Fur Animals", which has been reprinted as Yearbook Separate No. 1717 (U.S. Govt. Printing Office, 1940). It contains in 22 pages a summary of the scientific work carried out at the four or five experimental stations in the United States where nutritional research with fur animals has been carried out. It is impossible to indicate the findings here; but they should be of value to breeders of fur animals in this country, whenever circumstances permit again the development of the fur-farming industry.

\section{A Flooded Power Station}

ON August 20, 1939, a flood occurred at Tientsin in China which is stated to have been of unprecedented dimensions even for that part of the Far East, where floods are not infrequent. Mr. F. A. Matthews, chief engineer of the Electricity Department, British
Municipal Council, Tientsin, tells a graphic story of this terrible flood, according to the Electrical Times of August 8. Despite elaborate precautions, within a few hours the water forced its way into the station basements of the hydro-electric plant until the depth of the water was $6 \mathrm{ft} .6 \mathrm{in}$., and the power station was crippled for five weeks. The dyking of the power station compound and entrance was commenced immediately and in about four weeks it was possible to hold the flood waters at a safe level by pumps. Reconditioning of the flooded auxiliaries followed, and on September 24 the department was able to take over the load of the area from the Belgian Tramways Co., which had been giving a temporary supply.

The two large Metro-Vick turbo sets, each of 2,500 kw. capacity, had perforce to stop during the floods, and the opportunity was taken to recondition them. Alterations and improvements were also made in the boiler plant, giving marked betterment in coal consumption and heat recovery. Earlier in the year, restrictions and blockade had had an adverse effect on load conditions generally and many factories had to shut down. Members of the Electricity Department staff living outside the concession found it extremely difficult to get to and from their homes, and they had therefore to be housed within the Concession's boundary. In the latter part of the year, load conditions improved, and records were made by both income and profits.

\section{July Earthquakes}

THe U.S. Coast and Geodetic Survey in co-operation with Science Service and the Jesuit Seismological Association has made a preliminary determination of the epicentres of five earthquakes which occurred during the early part of July 1940. The first on July 6 had an epicentre in the sea to the north of Toco in Trinidad, and a fairly deep focus, probably of the order of $175 \mathrm{~km}$. The second on July 10 took place to the north-east of Kirin in Manchukuo. This may have been a very deep focus earthquake with a depth of focus in the neighbourhood of 450 $\mathrm{km}$. The third on July 13 was in the Pacific Ocean to the south of P. Burica in Central America. The fourth on July 14 had an epicentre near Rat Island in the Aleutian Islands group, and the fifth on July 19 had its epicentre in the sea bed to the north of Attu also in the Aleutian Islands group. The above determinations, based on reports from twenty-two seismographic stations, indicate the continuation of recent activity in the Aleutian Islands, and off the Pacific coast of Central America. The shock near Trinidad is a continuation of previous activity and the deep focus earthquake near Kirin extends to the north-west the previously known Japanese deep-focus portion of the circum-Pacific belt.

\section{Indian Statistical Conference}

THE second session of this Conference was held in Lahore in January 1939 ; the Proceedings were published in March 1940 and were received here in August (Edited by P. C. Mahalanobis. Pp. ii +168 . Calcutta : 
Statistical Publishing Society, 1940.) As in the first session a year before, there were sections dealing with theoretical statistics, agricultural statistics, and economic statistics, but an anthropological section has been added. The medical and public health section has disappeared, which is rather surprising, in view of the recent creation of the new post of medical statistician to the Government of India and a separate post for vital statistics at the All-India Institute of Hygiene and Public Health. The annual review by the general secretary, Prof. P. C. Mahalanobis, recalled the long association of the Punjab with statistical work. The study of the connexion between snowfall in the Punjab hills and the monsoon in North India formed the basis of Sir Gilbert Walker's work on weather correlations and his statistical method for long-range forecasting of the monsoon. This led to the concept of world weather; for example, the monsoon in India is controlled by weather conditions six months earlier in Java, Africa, or South America. It was also in the Punjab that pioneer work was done by Mr. Jacob on the influence of rainfall on the yield of wheat. Statistics has played an important part in the Punjab irrigation projects. In the year under review, extensive researches have been carried out in the field and laboratory for the improvement of the jute forecast, a problem of the greatest economic importance for India. The Statistical Institute has actively helped the Government of Bengal in an elaborate crop-cutting experiment for estimating the out-turn of rice. A report has been prepared on certain anti-mosquitr experiments undertaken by the Bengal Public Health Department for the control of malaria. A diet survey on a random sample basis has been started in Calcutta. Work has also been carried' out on varioús topics in theoretical 'statistics.

\section{Education in India}

THE "Progress of Education in India, 1932-1937" by John Sargent (Government of India Press, Simla, 5s.) is a paper book of $\mathbf{2 8 5}$ pages, well supplied with statistics and diagrams. The report deals with the period before Mr. Sargent became educational commissioner, and we share his feeling that the years which elapse while publication is delayed should be reduced to a minimum. The material is, indeed, vast, but surely the reports of various provinces can be secured and summarized within a year of their receipt. The period has been one of special difficulty, due to financial stress, which did not justify the optimism of the previous report. Several provinces speak strongly about the cramping of education, but retrenchment introduced on economic grounds is being gradually relaxed. Depression has produced a consensus of opinion that the present system is not practical enough in view of the needs of later life-a point in which the United States takes the lead. Secondary education in India needs particular attention.

The Central Advisory Board of Education, abolished in 1923, was revived in 1935 and has received the comments of two experts from England. It was found to be nzeded when control was handed over to the provinces, and there is enough evidence of that in this report. The Bureau of Education at headquarters was also abolished and revived. The decrease in the number of schools is largely to be attributed to wise measures of consolidation. We note, however, that in five provinces privately managed schools made the cost per pupil lower than in others. But in the whole of British India "the percentage of pupils attending all types of schools to the total population is 5-2 only". This is clearly not enough. Local autonomy has its defects as well as its advantages. Action is taken on grounds other than educational. Party strife and personal reasons have intervened, and the power that membership of a committee gives is noted as used unsatisfactorily in the Central Provinces. Inspectors are not pleased. This is a deep-rooted evil, and it will take some time to create a proper and general sense of responsibility among Indian managers of education.

\section{Announcements}

By an Order of the Committee of Privy Council, the Right Hon. James Gray Stuart, M.P., has been appointed a member of the Medical Research Council in the vacancy caused by the resignation of Mr. R. K. Law, M.P. By another Order, made after consultation with the Medical Research Council and with the President of the Royal Society, Sir W. Wilson Jameson, dean of the London School of Hygiene and Tropical Medicine, has been appointed to be a member of the Council in succession to Prof. Matthew J. Stewart, who retires in rotation on September 30.

Ir is announced in Science that Prof. Carl Neuberg, formerly professor in the University of Berlin, for twelve years director of the Kaiser Wilhelm Institute for Biochemistry until his retirement with the title emeritus in 1937, has been appointed research professor of chemistry in the Washington Square College of Arts and Scienees of New York University. He will take up the work in September, following his arrival in the United States from Palestine, where he has been teaching at the University of Jerusalem.

THE Borden award of a medal and a thousand dollars for research in nutrition was recently made to Dr. Henry C. Sherman, Mitchill professor of chemistry, Columbia University, New York, for his researches on enzymes, vitamins and the mineral elements in nutrition.

Messrs. W. AND J. George LTD., proprietors of F. E. Becker and Co., have recently issued a new 96 -page price list of laboratory chemicals, analytical reagents, stains and solutions. A feature which will commend itself at once is the setting out in the body of the list of the maximum limits of impurity to which the analytical reagents conform; and each bottle of 'Nivoc Analytical Reagent' now bears a guarantee to this effect. 